\title{
World Library and Information Congress: 73rd IFLA General Conference and Council. "Libraries for the future: Progress, Development and Partnerships" \\ 19-23 August 2007, Durban, South Africa
}

\author{
Lyudmila Ocholla - locholla@pan.uzulu.ac.za, University of Zululand Library, South Africa
}

\section{Introduction}

The development, purpose, composition, activities and programs of IFLA are covered in a number of publications, key of which are the IFLA Journal and IFLA website (http://www.icc.co.za/DurbanTour//6.aspx). IFLA (The International Federation of Library Associations and Institutions) is a leading international body representing the interests of library and information services and their users - the global voice of the library and information profession. IFLA is 80 years old and was founded in Edinburgh, Scotland, in 1927. Currently, the organisation is housed in the Netherlands, where the Hague's Royal Library supplies IFLA with its facilities. IFLA has 1700 members in over 150 countries and is an independent, international, non-governmental, not-for profit organisation.

Summarily, the aims of IFLA are:

- to promote high standards for the provision and delivery of library and information services;

- to encourage a widespread understanding of the value of good library \& information services;

- to represent the interests of IFLA members throughout the world (http://www.ifla.org/lll/index.html).

IFLA's core values are:

I. The endorsement of the principles of freedom of access to information, ideas and works of imagination and freedom of expression embodied in Article 19 of the Universal Declaration of Human Rights.

2. The belief that people, communities and organizations need universal and equitable access to information, ideas and works of imagination for their social, educational, cultural, democratic and economic well-being.

3. The conviction that delivery of high quality library and information services helps guarantee that access.

4. The commitment to ensure that all members of the federation engage in, and benefit from, its activities without regard to citizenship, disability, ethnic origin, gender, geographical location, language, political philosophy, race or religion (http:// www. ifla.org/lll/index.html).

The IFLA membership is divided into two categories, i.e. association members and institutional members. Eighty percent of the organizational income comes from its membership fees. IFLA has ongoing and established working relations with organizations such as UNESCO, and has established an observer status with the United Nations, World Intellectual Property Organization (WIPO), and International Organization for Standardization (ISO), among others. IFLA conferences are held once a year and each time in a different country. Five years ago, Durban (South Africa) was chosen to host the World Library and Information Congress: IFLA General Conference, in 2007. The theme of the conference was "Libraries for the future: Progress, Development and Partnerships" (see $h t t p: / / w w w . i f l a . o r g / l l l / i n d e x . h t m l)$.

\section{Conference location}

IFLA conference was held in Durban, which is the second largest city in South Africa and Africa's leading conference destination (http://www.icc.co.za/DurbanTour / 6.aspx. The International Convention centre (ICC) was the right venue to host the conference 2007, as it is one of the most advanced conference facilities in the world, and can accommodate up to 10000 delegates at such events.

\section{Organisation and participation}

The National Committee (formerly National Advisory Committee) was set up to organize and prepare the IFLA Conference in 2007. There was enormous amount of work done in the marketing of the event both locally and internationally, and in the organization, administration and management of the congress. Arguably, one of the reasons for holding the conference in different countries is to stimulate more participation in particular regions. This is the second 
time the African continent has hosted the event (the first being Nairobi, Kenya, in 1983). The benefits of having a conference on the African continent were in the numbers. There were 1606 delegates from Africa , the majority of whom were South Africans ( 1212 delegates, including exhibition and day visitors). Large delegations also came from the USA (488), UK (23I), China (122), and the Russian Federation (97). According to the IFLA Express No.8, a daily newspaper published during the conference, the conference attracted 2427 full time delegates and 349 day delegates from I I 8 countries, 202 accompanying persons, and 33 exhibition visitors of whom 43 I were first timers. 202 people were able to attend the conference through generous grants from various sources, such as the South African Department of Arts and Culture, National Research Foundation, EBSCO, SABINET, US Embassy in SA and others. LIASA arranged for its members to volunteer their services to the conference, and 122 volunteers from different libraries were working even before the conference started. The exhibition area was highly popular, covering a floor space of 1050 square meters, with 102 exhibitors providing delegates with the latest library and information products and innovations. There were 80 poster sessions covering different topics.

\section{The Conference programme}

IFLA consists of 8 divisions, i.e. General Research Libraries (Div I), Special Libraries (Div II), Libraries Serving the General Public (Div III), Bibliographic Control (Div IV), Collections and Services (Div V), Management and Technology (Div VI), Education and Research (Div VII) and Regional Activities (Div VIII). The conference had a total of 215 meetings, with 33 making use of simultaneous interpretation. Most of the conference papers (393) were presented in English (226), but there were also papers in French (98), Spanish (35), German (I7), Russian (I2), Chinese (4) and Arabic (I).

The opening ceremony of the 2007 World and Information Congress, the $73^{\text {rd }}$ IFLA General Conference \& Council was spectacular. South Africa's “Mother of Books", Gcina Mhlope, who is also one a popular storyteller, warmly welcomed all the delegates and speakers. A gigantic book was displayed on the stage, and school children were sitting around it, appearing to listen to Gcina Mhlope's stories. Her stories focused on the power of books that emanate from within the African context. The stories were accompanied with songs and dances of young musicians and dancers from KwaZulu Natal and professional Zulu dancers. The manner in which she introduced the invited speakers and participants by country was also engaging. She introduced conference speakers one by one with the assistance of the school children, who turned the pages of the "giant" book, with a given speakers' name each page. Dr. Alex Byrne, IFLA's President, gave an exciting opening address. He noted the following:

The theme of this Congress, 'Libraries for the future: Progress, Development and Partnerships', encapsulates many of our priorities. It speaks of our need to work together, in partnership, to achieve our goals including the development of our libraries and information services and our associations. Through them, we contribute to the development of our nations and of a fair and just world, a world in which we can progress towards an information society for all. In working towards that aim, we will truly create libraries for the future and demonstrate that the seeds of a just and fair future lie, at least in part, in libraries, in our important work" (2007:260)

His presentation was followed by a welcome address by Ms Ellen Tise, Chair of the National Committee and IFLA President elect. Dr. Z. Pallo Jordan, South Africa's National Minister of Arts and Culture, and an extraordinary intellectual in the way of associating libraries with the struggle for the liberation of the country from apartheid, provided an insight into the development of libraries in South Africa in terms of the past, the present and the future, stressing the government's commitment in terms of policy and funding (see http://www.dac.gov.za/). The Keynote speaker was none other than Justice Albie Sachs, from the Constitutional Court of SA, who gave a very interesting, stimulating and and inspiring speech about how libraries and books helped him while he was in solitude confinement for having challenged the apartheid regime. Among others, he distinguished between "libraries on legs", which focus on people as sources of information that may not be ignored by modern libraries and information services, and "libraries as heavens", where the emphasis is on the provision of safe reading places for individuals and communities whose home environment cannot offer suitable reading condition because of factors such as congestion (commonly found in slums, ghettos, information poor environments, fourth world conditions).

As mentioned earlier, the significance of this conference lies in the fact that it was IFLA's second time in Africa after 24 years and the first time in South Africa and the event coincided with the $10^{\text {th }}$ anniversary of LIASA and $80^{\text {th }}$ anniversary of IFLA. The conference also attracted the largest number of delegates from Africa who would not have attended an IFLA conference had it not been for the conference location and the travel support received from philanthropists such as the South African government. Lastly, South Africa and LIASA were able to showcase their conference organisation abilities, providing exceptional hospitality and entertainment in the form of library visits and the Beach Party, a wonderful conference opening, an extraordinary conference venue and excellent conference organisers. This conference was I 
memorable, and has left a lot for the South African and African library and information service community to consider and aspire to achieve.

\section{References}

Byne, Alex.2007. Libraries for the future: progress.development an partnerships. Opening address, World Library and Information Congress, Durban. IFLA Journal, Vol.33, No.3, 158-260 